\title{
Checklist of the hard tick (Acari: Ixodidae) fauna of Hungary with emphasis on host-associations and the emergence of Rhipicephalus sanguineus
}

\author{
Sándor Hornok ${ }^{1} \cdot$ Dávid Kováts ${ }^{2,3} \cdot$ Gábor Horváth $^{4} \cdot$ Jenő Kontschán ${ }^{5} \cdot$ Róbert Farkas $^{1}$
}

Received: 14 October 2019 / Accepted: 24 December 2019 / Published online: 6 February 2020

(c) The Author(s) 2020

\begin{abstract}
Hungary is situated in the southern part of Central Europe, next to the northern boundary of the Mediterranean region. This geographical position may allow the northward expansion of Mediterranean ixodid tick species into Hungary, particularly in the era of warming climate. During the past 14 years numerous surveys have been published on the species and activity of hard ticks occurring in the country. However, it was 60 years ago that the last comprehensive review of ixodid ticks of Hungary was published, and only in Hungarian language. The purpose of the present checklist is to provide a comprehensive and complete overview of the ixodid fauna of Hungary, based on tick reports published so far in Hungarian or English, also including hitherto unpublished data. Altogether 27 hard tick species were identified in Hungary, of which 21 can be regarded as indigenous. Most importantly, the autochthonous occurrence of Rhipicephalus sanguineus sensu lato was not known prior to 2005, but during the last 14 years increasing numbers of cases have been reported, attesting the emergence of this tick species in Hungary. Whereas $R$. sanguineus sensu lato was always associated with dogs and cats in Hungary, other tick species show differences in host associations according to habitat type, seasonal activity and questing height. Changes in the distribution, abundance and seasonality of a few tick species were also noted.
\end{abstract}

Keywords Hard ticks · Ecology · Distribution · Habitat · Ornithophilic · Chiropterophilic · Pholeophilic $\cdot$ Nidiculous

\section{Sándor Hornok}

Hornok.Sandor@univet.hu

1 Department of Parasitology and Zoology, University of Veterinary Medicine, Budapest, Hungary

2 Ócsa Bird Ringing Station, Ócsa, Hungary

3 Hungarian Biodiversity Research Society, Budapest, Hungary

4 Veterinary Authority, Csurgó, Hungary

5 Plant Protection Institute, Centre for Agricultural Researches, Budapest, Hungary 


\section{Introduction}

Hungary has a continental climate and is situated in the southern part of Central Europe, next to the northern boundary of the Mediterranean region. This geographical position may allow the northward expansion of Mediterranean tick species into Hungary, since there are no continuous mountain ranges bordering the country from the south. Recently, this scenario has become more likely than ever, as a consequence of the warming climate. This may affect Hungary, among the other consequences, with the emergence of thermophilic tick species, because in Europe the increase of annual mean temperature will probably exceed the global warming rate in the 21 st century (Bartholy et al. 2007).

This was one of the reasons why increasing importance was attributed to monitoring tick activity along the southern border of Hungary (Hornok and Farkas 2009) and in the context of bird and bat migration (e.g. Hornok et al. 2016a, b). Parallel with this, groundbound host species were also regularly sampled for ticks (e.g. Földvári and Farkas 2005a; Rigó et al. 2011; Földvári et al. 2011; Hornok et al. 2012a). These surveys resulted in an upsurge of publications between 2005 and 2019 on tick species occurring in the country. However, it was as long as 60 years ago that the last comprehensive review of ixodid ticks of Hungary was published, and only in Hungarian language (Janisch 1959). After that, as part of Fauna Hungariae, an identification guide was compiled (Babos 1965). Although it was also published in German language (Babos 1964), several species in that book were later synonymized with other species.

In light of the above, this concise review is built around three issues: (1) past data (from 1959-1973) on ticks hitherto published in Hungarian, (2) recent data (from 2005-2019) published in English and (3) new, not yet published data. This implies that a significant part of the data summarized here has not been available for the international community.

Considering the whole of Central Europe, comprehensive data are only available from a few countries (as exemplified by Germany: Petney et al. 2012), but are lacking from several countries neighboring Hungary. Therefore, data presented in this review may be highly relevant to a broader geographical region than only to Hungary and should be taken into account when assessing risks of tick-borne diseases or inadvertent transportation of ticks together with their host. This international relevance is further enhanced by focusing on host spectra of tick species.

\section{Methods}

\section{Sources of unpublished data}

Previously unpublished data were included here from the following studies.

(1) During 2005-2008, 1173 ticks (Ixodes ricinus, Dermacentor marginatus, D. reticulatus, Haemaphysalis concinna, Ha. inermis, Ha. punctata) were collected from large game animals (Cervus elaphus, Capreolus capreolus, Dama dama, Sus scrofa) at 76 locations (in 16 out of 20 counties) of Hungary (organized by Róbert Farkas); 
(2) During 2005-2012, 7 ticks (Ha. concinna, Ha. punctata and Hy. marginatum) were collected from horses in southwestern Hungary (Somogy and Zala counties) (by Róbert Farkas, Gábor Földvári, Sándor Hornok and Levente Szilvássy);

(3) In 2016, 8 ticks (I. ricinus and Ha. punctata) were collected from dogs in northern Hungary (Nógrád county) (by Sándor Hornok and Sándor Kovalcsik);

(4) During 2006-2019, 76 ticks (I. canisuga, I. hexagonus, Ha. concinna, Ha. punctata and Rhipicephalus sanguineus sensu lato) were collected from dogs and cats at 16 locations (in Budapest and in Pest, Nógrád, Heves, Fejér, Veszprém, Somogy, Baranya counties) (by Róbert Farkas);

(5) In 2017, 154 ticks (I. ricinus, D. reticulatus, Ha. concinna) were collected from golden jackals in southwestern Hungary (Somogy county) (by Gábor Horváth).

Tick species were identified using standard morphological keys (Babos 1965; EstradaPeña et al. 2017). The species and subspecies of Ha. erinacei erinacei (reported as Haemaphysalis sp. in Hornok and Farkas 2005) was determined in this study, under a VHX-5000 digital microscope (Keyence, Osaka, Japan).

\section{Data presentation}

To maintain the concise nature and user friendliness of this list, we do not mention broader, Palearctic distribution, general ecology and vector role of tick species found in Hungary. This information is available in recently published sources (e.g. Estrada-Peña et al. 2017). Earliest data (e.g. Kotlán 1921) were not used, because of missing or vague information on the exact localities. For the great majority of records (historical: Figs. 1-2, more recent:

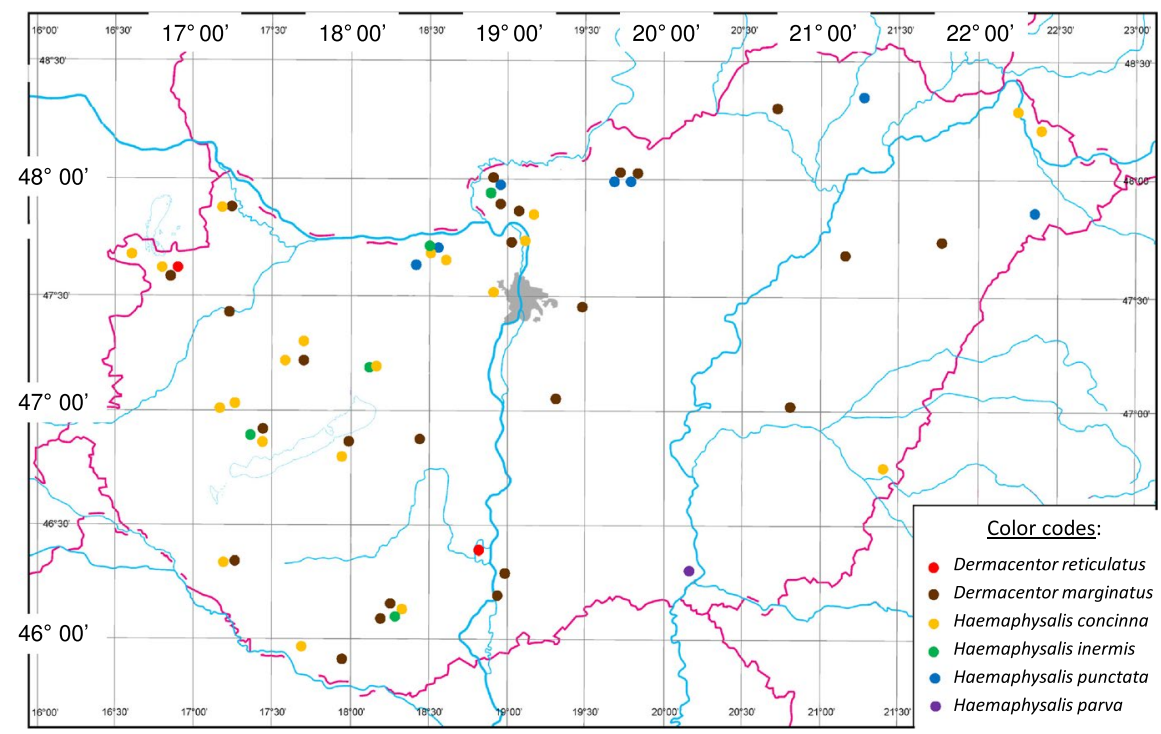

Fig. 1 Map of Hungary showing historical collection sites of Dermacentor and Haemaphysalis species, adults of which quest on the vegetation (i.e. are collectable with dragging-flagging), based on data from 1959-1973 (Janisch 1959, 1973; Molnár 1982). Ixodes ricinus was reported to be ubiquitous, without geographical data (Janisch 1959), therefore not shown 


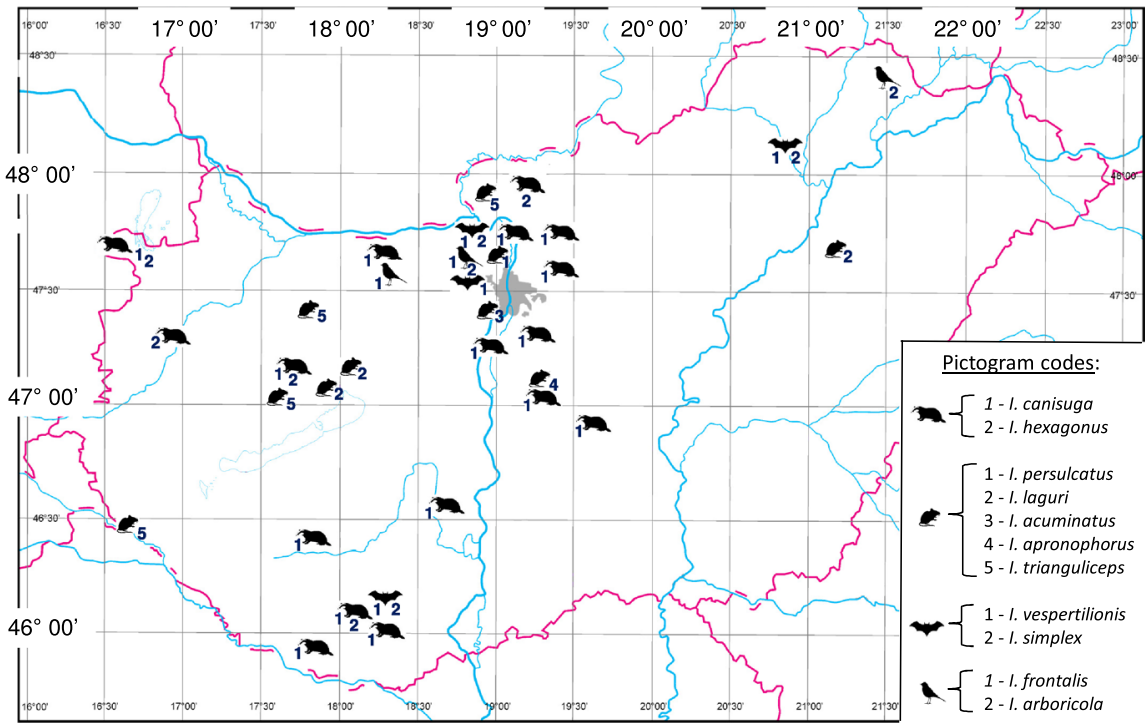

Fig. 2 Map of Hungary showing historical collection sites of Ixodes species other than I. ricinus, which are nidiculous or pholeophilous (i.e. mostly collected from their hosts), based on data from 1959-1973 (Janisch 1959, 1973; Molnár 1982). Pictograms: =tick species usually associated with carnivores and hedgehogs; $=$ tick species most frequently associated with rodents; $=$ tick species associated with bats; = $=$ ornithophilic tick species

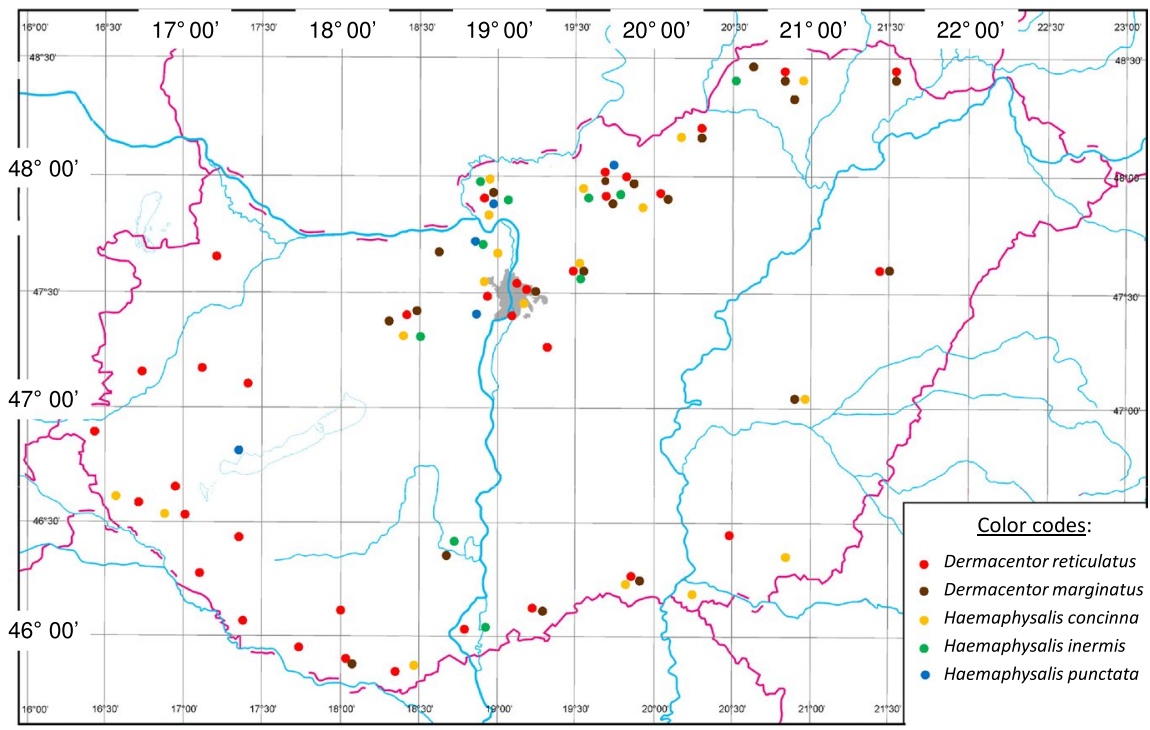

Fig. 3 Map of Hungary showing collection sites of Dermacentor and Haemaphysalis species, adults of which quest on the vegetation (i.e. are collectable with dragging-flagging), based on data from 2004-2019 (according to Hornok and Farkas 2009, but also including locations from references cited in the main text). Ixodes ricinus was found at all collection sites in Hornok and Farkas (2009), therefore not shown separately 


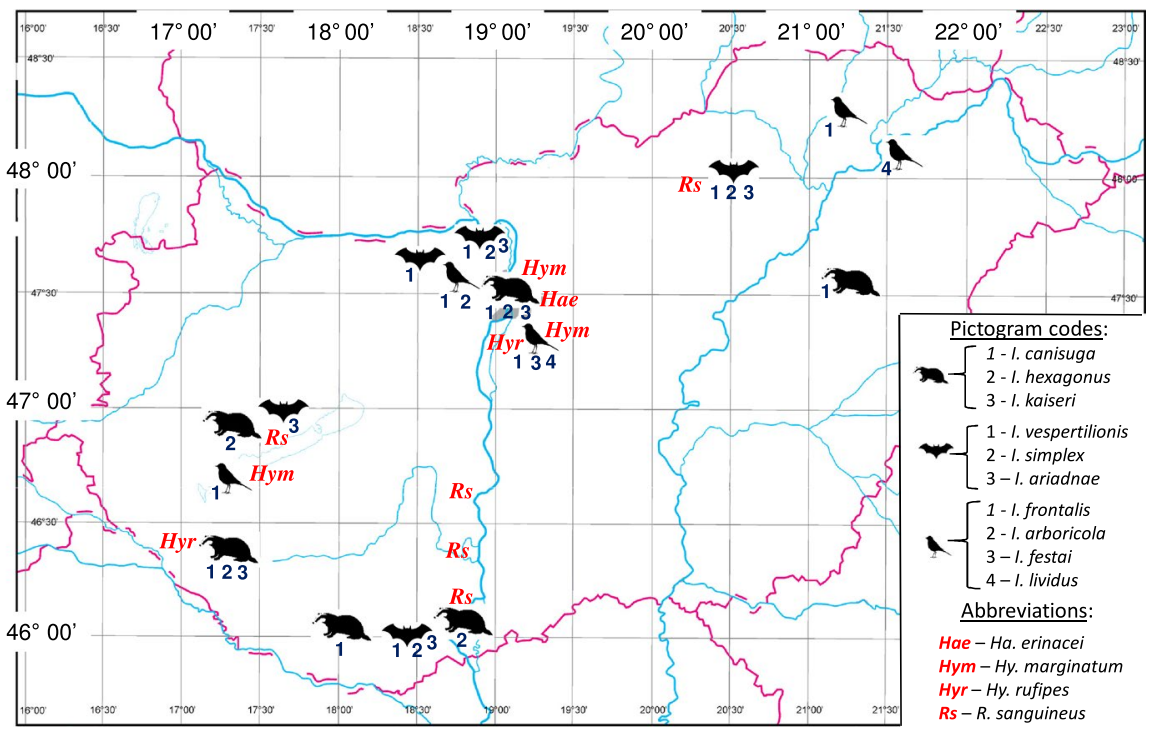

Fig. 4 Map of Hungary showing collection sites of Ixodes species other than I. ricinus, which are nidiculous or pholeophilous (i.e. mostly collected from their hosts), based on data from 2004-2019 (for references see main text). In addition, collection sites of emerging or newly identified tick species are shown with red, bold initials of genus and species names. Pictograms: =tick species usually associated with carnivores and hedgehogs; $=$ tick species associated with bats; $=$ ornithophilic tick species

Figs. 3-4) only geographical names of villages, cities, mountains are available, therefore coordinates are not used in the dataset (but can be retrieved from www.google.com/ maps according to the name of locality). On the maps of tick distribution based on collections from hosts (Figs. 2, 4), locations are only shown according to region (i.e., without separation of places within $50 \mathrm{~km}$ distance from each other) for those tick species, which are associated with potentially migrating or at least mobile wild animal species. The latter include birds, bats and carnivores, which, unlike domestic animals, are not confined in their locality, therefore the exact place of the origin of their tick infestation is unknown.

Tick species names are used sensu Guglielmone et al. (2014), and valid names for synonyms (mentioned in Babos 1965) according to Camicas et al. (1998). Latin names of host species are listed in alphabetical order within taxonomic units. Host group or species name (whichever relevant) is followed by tick developmental stages (L: larva, N: nymph, A: adult, T: all three stages) if this information was available. Taking into account the multiplicity of identical genus name initials among listed host species, only consequent, identical genus names are abbreviated. Locations of historical data (1959-73) are marked with asterisk $(*)$ in the text.

\section{Ixodid tick species indigenous (completing their life cycle) in Hungary}

\section{Ixodes ricinus (L.)}

Hosts: Reptiles (L, N)—Lacerta viridis, L. agilis, Podarcis tauricus.

Birds (L, N)-mainly Passeriformes: Acrocephalus arundinaceus, A. palustris, A. schoenobaenus, A. scirpaceus, Anthus trivialis, Carduelis cannabina, C. chloris, 
Coccothraustes coccothraustes, Corvus cornix, Emberiza citrinella, E. schoeniclus, Erithacus rubecula, Fringilla coelebs, Garrulus glandarius, Lanius collurio, Locustella luscinioides, Luscinia luscinia, L. megarhynchos, Parus major, Passer domesticus, P. montanus, Pica pica, Phylloscopus collybita, Prunella modularis, Sitta europaea, Sturnus vulgaris, Sylvia atricapilla, S. communis, S. nisoria, Troglodytes troglodytes, Turdus iliacus, T. merula, T. philomelos, T. pilaris, T. viscivorus; also Strigiformes: Strix aluco; Accipitriformes: Buteo buteo, Milvus migrans; Gruiformes: Crex crex; Galliformes: Perdix perdix, Phasianus colchicus, Tetrastes bonasia.

Mammals_various orders: Apodemus flavicollis (L, N), A. sylvaticus (L), A. agrarius, Bos taurus domesticus (N, A), Canis aureus (A), C. lupus familiaris (L, A), Capra aegagrus hircus (T), Capreolus capreolus (T), Cervus elaphus (N, A), Dama dama (A), Equus ferus caballus (A), Erinaceus roumanicus (N, A), Felis silvestris catus (A), Felis silvestris silvestris (T), Homo sapiens (N, A), Lepus europaeus (T), Martes foina (A), Meles meles $(\mathrm{N}, \mathrm{A})$, Micromys minutus (L), Microtus arvalis (L, N), Microtus subterraneus $(\mathrm{L}, \mathrm{N})$, Muscardinus avellanarius (L, N), Myodes glareolus (L, N), Neomys fodiens (L, N), Ovis aries aries (N, A), Sciurus vulgaris (L, N), Sorex araneus (L), Sus scrofa (N, A), Talpa europaea (L), Vulpes vulpes (A).

Distribution: Countrywide.

Ecology: In forested habitats, up to altitudes of 900-1000 m a.s.l.; year-round, but biphasic (higher spring and lower autumn) activity, peaking in May; larvae and nymphs typically on lizards, ground feeding birds, rodents; adults on hedgehogs and larger mammals.

References: Janisch (1959, 1960, 1973); Janisch and Szabó (1961); Babos (1965); Molnár (1982); Sréter et al. (2003); Földvári and Farkas (2005a); Földvári et al. (2009, 2011); Hornok (2009); Hornok and Farkas (2009); Rigó et al. (2011); Hornok et al. (2012a, b, 2013b, 2014b, d, 2016a, 2017c); Farkas et al. (2014).

\section{Ixodes hexagonus Leach}

Hosts: Canis lupus familiaris (A), Erinaceus roumanicus (N, A), Felis silvestris catus, Meles meles (A), Vulpes vulpes.

Distribution (Figs. 2, 4): widespread (western Hungary: Sopron*, Csurgó, Nagybajom, Porrogszentkirály, Sárcsikút*; northern-central Hungary: Törökbálint, Budapest, Borsosberény*; southern Hungary: Sümeg, Mohács, Pellérd*).

Ecology: Pholeophilous (burrows, caves); March-November (E. roumanicus), March and May (M. meles); March, May and July (C. lupus familiaris); April, May and July (Felis silvestris catus).

References: Janisch (1959, 1973); Janisch and Szabó (1961); Földvári and Farkas (2005a); Hornok et al. (2018).

\section{Ixodes canisuga Johnston}

Hosts: Canis aureus (N), C. lupus familiaris (A), Martes foina, Meles meles (L, A), Mustela nivalis, M. putorius, Vulpes vulpes (T).

Distribution (Figs. 2, 4): widespread (western Hungary: Nagybajom, Porrogszentkirály, Németbánya*; northern-central Hungary: Törökbálint, Budapest, Gödöllő*, Vác*; southern Hungary (Vókány*, Kaposvár*; eastern Hungary: Hortobágy). 
Ecology: Pholeophilous (burrows); December, March and April (M. meles), April-June (C. lupus familiaris), June-August (C. aureus, V. vulpes).

References: Janisch (1959, 1973) (syn. I. vulpinus); Babos (1965) (syn. I. melicola, I. vulpinus, I. vulpis, I. danyi); Sréter et al. (2003); Hornok et al. (2013b, 2017a, 2018).

\section{Ixodes kaiseri Arthur}

Hosts: Canis lupus familiaris (A), Meles meles (N).

Distribution (Fig. 4): widespread (western Hungary: Porrogszentkirály, Bakony Mountains*; central Hungary: Budapest).

Ecology: Pholeophilous (burrows); December (M. meles), January and April (C. lupus familiaris).

References: Babos (1965) (syn. I. bakonyensis); Hornok et al. (2017a, 2018).

\section{Ixodes acuminatus Neumann}

Hosts: Canis lupus familiaris (A), Cricetus cricetus (A), Erinaceus roumanicus (N).

Distribution (Figs. 2, 4): widespread (central Hungary: Budafok*, Budapest; southeastern Hungary: exact location not reported).

Ecology: Nidiculous; May and October (C. cricetus),

References: Janisch (1959) (syn. I. redikorzevi); Földvári et al. (2007, 2011); Rigó et al. (2011).

\section{Ixodes apronophorus Schulze}

Hosts: Arvicola amphibius, Microtus oeconomus, Sorex araneus (N).

Distribution (Fig. 2): sporadic (central Hungary: Tatárszentgyörgy*).

Ecology: Nidiculous.

References: Janisch (1959, 1960).

\section{Ixodes trianguliceps Birula}

Hosts: Apodemus flavicollis (N), Myodes glareolus (A), Microtus agrestis, M. arvalis, Sorex araneus $(\mathrm{N})$, Talpa europaea $(\mathrm{L}, \mathrm{N})$.

Distribution (Fig. 2): sporadic (western Hungary: Letenye*, Sárcsikút*, Németbánya*, Vinye*, Pálihálás*; northern Hungary: Börzsöny Mountains*).

Ecology: Nidiculous; May-August.

References: Babos (1965); Janisch (1973); Molnár (1982).

\section{Ixodes laguri Olenev}

Hosts: Spermophilus citellus, Cricetus cricetus (N).

Distribution (Fig. 2): widespread (western Hungary: Gyulafirátót*, Öskü*, Vörösberény*; eastern Hungary: Hortobágy-Máta*).

Ecology: Nidiculous; July.

References: Janisch (1959, 1973); Babos (1965). 


\section{Ixodes vespertilionis Koch}

Hosts: Mainly Rhinolophidae: Rhinolophus hipposideros (T), R. euryale (A); rarely Vespertilionidae: Myotis bechsteinii (L), Plecotus auritus (L).

Distribution (Figs. 2, 4): mountainous regions of Hungary (caves of the Gerecse, Pilis and Mecsek Mountains, Bükk Highlands and Aggtelek National Park).

Ecology: Pholeophilous (caves); active in all seasons, with peak numbers in the spring.

References: Hornok et al. (2014a, 2016b).

\section{Ixodes ariadnae Hornok}

Hosts: Mainly Vespertilionidae: Myotis alcathoe (L, N), M. bechsteinii $(\mathrm{L}, \mathrm{N})$, M. blythii $(\mathrm{N})$, M. dasycneme $(\mathrm{L}), M$. daubentonii $(\mathrm{L}), M$. emarginatus $(\mathrm{L}, \mathrm{N}), M$. myotis $(\mathrm{L}, \mathrm{N}), M$. nattereri (L), Plecotus auritus (L, N); rarely Rhinolophidae: Rhinolophus hipposideros (L).

Distribution (Fig. 4): mountainous regions of Hungary (caves of the Bakony and Pilis Mountains, Bükk Highlands).

Ecology: Pholeophilous (caves); active in all seasons, peak numbers of larvae/ nymphs early autumn.

References: Hornok et al. (2014a, 2016b).

\section{Ixodes simplex Neumann}

Hosts: Almost exclusively Miniopteridae: Miniopterus schreibersii (T); rarely Vespertilionidae: Barbastella barbastellus (L), Myotis nattereri.

Distribution (Figs. 2, 4): mountainous regions of Hungary (caves of the Pilis, Villányi and Zemplén* Mountains, Bükk Highlands).

Ecology: Pholeophilous (caves); collected during early autumn.

References: Janisch (1959) (syn. I. chiropterorum); Hornok et al. (2014a, 2016b).

\section{Ixodes frontalis (Panzer)}

Hosts: Birds - Passeriformes: Sylvia atricapilla (A), Carduelis chloris (A), Garrulus glandarius, Parus major (L, A), Erithacus rubecula (T), Turdus merula, T. philomelos $(\mathrm{L}, \mathrm{N})$.

Distribution (Figs. 2, 4): widespread (western Hungary: Fenékpuszta; central Hungary: Gerecse* and Pilis* mountains, Ócsa; northeastern Hungary: along the river Bódva).

Ecology: Typically on ground feeding birds, predominantly in (early) spring (data unavailable on seasonality of local, questing ticks).

References: Babos (1965); Hornok et al. (2016a).

\section{Ixodes arboricola Schulze and Schlottke}

Hosts: Arboreal, mainly cavity-nesting birds - Passeriformes: Garrulus glandarius (A), Muscicapa sp., Sitta europaea (N); Piciformes: Dendrocopos major.

Distribution (Figs. 2, 4): sporadic (northern-central Hungary: Pomáz*; eastern Hungary: Háromhuta*). 
Ecology: Pholeophilous, in tree holes or nesting boxes (regional seasonality unknown due to low availability).

References: Janisch (1959) (syn. I. dryadis); Babos (1965) (syn. I. passericola).

\section{Ixodes lividus Koch}

Hosts: Birds (host specific parasite of Riparia riparia).

Distribution (Fig. 4): according to hosts (middle Hungary: Ócsa, and mainly eastern Hungary, along the river Tisza: Rakamaz).

Ecology: Pholeophilous, in the burrows, nests of its hosts; from April to October.

References: Szép and Møller (1999); Hornok et al. (2016a).

\section{Haemaphysalis parva (Neumann)}

Hosts: Lepus europaeus (A), Equus ferus caballus.

Distribution (Fig. 2): southern Hungary: Szeged*

Ecology: Habitat and seasonality unknown due to rare identification.

Reference: Janisch (1959) (syn. Ha. otophila).

\section{Haemaphysalis concinna Koch}

Hosts: Birds (L, N)—mainly Passeriformes: Acrocephalus palustris, A. schoenobaenus, A. scirpaceus, Anthus trivialis, Carduelis chloris, Coccothraustes coccothraustes, Emberiza citrinella, E. schoeniclus, Erithacus rubecula, Locustella luscinioides, L. naevia, L. megarhynchos, Parus major, Prunella modularis, Sylvia atricapilla, Turdus merula, T. philomelos; rarely Accipitriformes: Milvus migrans.

Mammals-various orders: Canis aureus (L, N), C. lupus familiaris (T), Capra aegagrus hircus (T), Capreolus capreolus (T), Cervus elaphus (T), Dama dama (A), Equus ferus caballus (A), Felis silvestris catus, F. silvestris silvestris (N), Lepus europaeus (L, $\mathrm{N})$, Meles meles $(\mathrm{N})$, Ovis aries aries (A), Sciurus vulgaris $(\mathrm{L}, \mathrm{N})$, Vulpes vulpes $(\mathrm{T})$.

Distribution (Figs. 1, 3): countrywide.

Ecology: Forested habitats; monophasic late spring to early autumn activity (peaking in May); larvae and nymphs typically on bird species feeding above the ground level (predominantly in summer), and on cervids, carnivores.

References: Janisch and Szabó (1961); Janisch (1973); Molnár (1982); Sréter et al. (2003); Földvári and Farkas (2005a); Hornok (2009); Hornok and Farkas (2009); Gyuranecz et al. (2011); Hornok et al. (2012a, 2013b, 2014d, 2016a, 2017c, 2018); Farkas et al. (2014).

\section{Haemaphysalis punctata Canestrini and Fanzago}

Hosts: Birds (L, N)—mainly Passeriformes; Corvidae: Corvus cornix, Pica pica, Garrulus glandarius and Turdidae: Turdus merula, T. torquatus.

Mammals-Bos taurus domesticus (A), C. lupus familiaris (A), Cervus elaphus (A), Ovis aries aries (A).

Distribution (Figs. 1, 3): regional (western Hungary: Balatonederics, northern-central Hungary: Pilis Mountains, Érd; northeastern Hungary: Bátonyterenye, Tar, Heves county). 
Ecology: Partly dry habitats (shrubs) associated with southern slopes; biphasic activity peaking in March-May and September.

References: Janisch (1960); Janisch and Szabó (1961); Hornok (2009); Hornok and Farkas (2009); Hornok et al. (2014c).

\section{Haemaphysalis inermis Birula}

Hosts: Bos taurus domesticus (A), Cervus elaphus (A), Dama dama (A), Homo sapiens (A), Sus scrofa (A).

Distribution (Figs. 1, 3): countrywide, with increasing abundance since 1965.

Ecology: Forested habitats with sparse tree covering and dense, green lower vegetation; monophasic activity associated with winter months, peaking in November.

References: Janisch and Szabó (1961); Hornok (2009); Hornok and Farkas (2009); Hornok et al. (2012b, 2017c).

\section{Dermacentor marginatus (Sulzer)}

Hosts: Rarely birds: Emberiza citrinella.

Almost exclusively mammals: Apodemus agrarius (L, N), Bos taurus domesticus (A), C. lupus familiaris (N, rarely A), Capra aegagrus hircus (A), Capreolus capreolus (A), Cervus elaphus (A), Cricetus cricetus (L, N), Dama dama (A), Equus ferus caballus (A), Felis silvestris catus, Homo sapiens (A), Lepus europaeus (L, A), Microtus arvalis (L, N), Ovis aries aries (A), Rattus norvegicus (L, N), Spermophilus citellus (L, N), Sus scrofa (A), Talpa europea (L, N), Vulpes vulpes.

Distribution (Figs. 1, 3): countrywide, except in western Hungary (where it was widespread in 1959, and was also reported at Csönge, Barcs, Kaposvár, Marcali, Nagyatád, Siófok in 1977, but not found during surveys in 2007, 2011).

Ecology: Larvae and nymphs nidiculous/pholeophilous; adults in open country habitats (meadows, pastures), up to altitudes of 900-1000 m a.s.1.; biphasic (high spring and low autumn) activity, peaking in March.

References: Janisch (1959, 1960, 1973); Janisch and Szabó (1961); Babos (1965); Molnár (1982); Földvári and Farkas (2005a); Hornok et al. (2007, 2012a, b, 2014d, 2017c); Hornok (2009); Hornok and Farkas (2009); Földvári et al. (2013); Pintér et al. (2013).

\section{Dermacentor reticulatus (Fabricius)}

Hosts: Bos taurus domesticus (A), Canis aureus (A), C. lupus familiaris (N, A), Capra aegagrus hircus (L, A), Capreolus capreolus (A), Cervus elaphus (A), Dama dama (A), Equus ferus caballus (A), Felis silvestris catus, Homo sapiens (A), Ovis aries aries (A), Sus scrofa (A), Vulpes vulpes (A).

Distribution (Figs. 1, 3): countrywide, with significant range expansion since 1959, when it was present only in two foci (Fertőd, Tolna); reported later in additional foci (1977: Csönge, Vát, Vasvár, Szentpéterfa, Nádasd; 1978: Csesztreg, Zalalövő; 1979-1986: southern shore of lake Balaton including Boglárlelle, southern shore of lake Velence and Mohács Island). 
Ecology: Larvae and nymphs nidiculous/pholeophilous; in river basins, surroundings of lakes, open country habitats (meadows, pastures), up to altitudes of 900-1000 m a.s.l.; biphasic (substantial spring, but higher autumn) activity, peaking in September-October.

References: Janisch (1959, 1986); Babos (1965); Rehácek et al. (1979); Molnár (1982); Sréter et al. (2003); Földvári and Farkas (2005a, b); Széll et al. (2006); Hornok et al. (2007, 2012a, b, 2013b, 2014d, 2017c); Hornok (2009); Hornok and Farkas (2009); Földvári et al. (2013); Farkas et al. (2014).

\section{Rhipicephalus sanguineus sensu lato (Latreille)}

Hosts: Canis lupus familiaris (T), Felis silvestris catus (A).

Distribution (Fig. 4): sporadic, local with increasing number of cases since 2005 (western Hungary: Kővágóörs [one female from a cat-July, 2007; one female from a dogAugust, 2010]; southern Hungary: Mohács [six females from a dog-August, 2014], Szekszárd [ten nymphs from a dog-2012]; central Hungary: Paks [13 females and 41 males from dogs-August, 2016]; northeastern Hungary: Eger [one female from a cat-August, 2019]).

Ecology: Associated with dogs and cats (particularly in kennels).

Reference: Hornok et al. (2017b) (Szekszárd), other data provided by R. Farkas.

\section{Ixodid tick species imported into Hungary by migratory birds, but not known to complete their life cycle}

\section{Ixodes festai Rondelli}

Hosts: Birds - Passeriformes: Carduelis chloris (A), Prunella modularis (A).

Distribution (Fig. 4): sporadic (central Hungary: Ócsa).

Ecology: Imported by northward migrating birds during the spring.

Reference: Hornok et al. (2016a).

\section{Ixodes persulcatus Schulze}

Hosts: Apodemus flavicollis (A).

Distribution (Fig. 2): sporadic (north Hungary: Pilis mountains).

Ecology: In forested habitats, where it was probably imported by southward migrating birds (data unavailable on seasonality).

Reference: Janisch (1959).

\section{Hyalomma marginatum Koch}

Hosts: Equus ferus caballus (A), Erinaceus roumanicus (N), Erithacus rubecula (L, N).

Distribution (Fig. 4): autochthonous occurrence on horse in southwestern Hungary (Balatonfenyves) and on hedgehog in central Hungary (Budapest), collected from birds in central Hungary (Ócsa).

Ecology: Nymphs arrive during spring (northward) bird migration; may molt to adult stage by autumn (adults on horse in November).

References: Földvári et al. (2011); Hornok et al. (2013a). 


\section{Hyalomma rufipes Koch}

Hosts: Bos taurus domesticus (A), Sylvia communis (N).

Distribution (Fig. 4): autochthonous occurrence on cattle in southwestern Hungary: Surd; collected from a bird in central Hungary: Ócsa.

Ecology: Nymphs arrive during spring (northward) bird migration; may molt to adult stage by autumn (adults on cattle in September).

References: Hornok and Horváth (2012), Hornok et al. (2016a).

\section{Ixodid tick species imported into Hungary with transportation of their hosts}

\section{Amblyomma dissimile Koch}

Hosts: Boa constrictor (A), Iguana iguana (A).

Distribution: In one case (non-autochthonous, neotropical i.e. unlikely to establish).

Ecology: Imported from South America with reptiles brought to the Budapest Zoo.

Reference: Janisch (1959).

\section{Haemaphysalis erinacei erinacei Pavesi}

Hosts: Ictonyx libycus (A).

Distribution (Fig. 4): in one case in Budapest (non-autochthonous, reported from Croatia, Romania, i.e. with the possibility to establish).

Ecology: Imported with a pet animal for sale.

Reference: Hornok and Farkas (2005).

\section{Discussion}

Since more than half a century (Janisch 1959; Babos 1965), this is the first updated, complete list of ixodid tick species occurring in Hungary. Taken together, 27 hard tick species have been recorded in the country, of which 21 can be regarded as indigenous (i.e., completing their life cycle in Hungary) with either sporadic or regular occurrence.

Considering tick species that have long been indigenous in Hungary, there seems to be no major difference in comparison with neighboring countries or other parts of Central Europe (Estrada-Peña et al. 2017). However, in the category of tick species imported into Hungary by migratory birds, to the best of our knowledge, I. festai, I. persulcatus and Hy. rufipes have not been reported in neighboring countries (Contini et al. 2011; Krčmar 2012; Mihalca et al. 2012; Estrada-Peña et al. 2017). Among tick species imported with the transportation of their host, this is the first identification of Ha. erinacei in Hungary, with the Libyan striped weasel (Ictonyx libycus) as a new host record. In addition, A. dissimile has only been reported on exotic reptiles in western Europe (cf. Mihalca 2015), therefore Hungary is the only Central European country, where this neotropical tick species was found.

Most importantly, several new foci of $R$. sanguineus are reported here for the first time in Hungary. In contrast to the non-indigenous status of this species (Janisch and Szabó 1961) and its previously anticipated (Babos 1965) and observed introductions (Hornok and Farkas 2005), these independent cases illustrate the growing importance and likely establishment of $R$. sanguineus in Hungary. This is especially true for places where multiple 
infestations of dogs were noted (all in southern-central Hungary: Mohács, Szekszárd, Paks), implying at least temporary populations. Confirming this possibility, tick-borne pathogens transmitted by this species have already been detected in southern Hungary (e.g. Ehrlichia canis and Rickettsia massiliae: Hornok et al. 2013b).

Similarly, cases of autochthonous infestation (i.e., of non-avian hosts) suggest that $H y$. marginatum and Hy. rufipes are able to molt to the adult stage under climatic conditions in Hungary. In addition, it is noteworthy that both cases of adult Hyalomma specimens (on horse and cattle) were observed in southwestern Hungary, which has the highest mean winter temperatures in the country. Therefore, the possibility of overwintering of Hyalomma species (as a prerequisite of population establishment) in Hungary cannot be excluded. In support of this, the geographical range of Hy. rufipes is limited to areas with up to 120 days of frost annually (Hoogstraal 1956).

Considering Hyalomma rufipes, it is hard to verify if Hy. impressum mentioned from imported livestock in Hungary (Babos 1965), is the same species or not, due to insufficient morphological characterization to distinguish it from Hy. impressum sensu stricto (especially because Babos mentioned the authority as Koch, who described in the same year, 1844, both Hy. rufipes and Hy. impressum as separate species). The same stands for $H y$. aegyptium aegyptium, lacking detailed morphological description (Kotlán 1921). Therefore, identification of Hy. rufipes in 2012 is considered as the first (bona fide) finding of this species in the country (Hornok and Horváth 2012), and due to its uncertainty Hy. impressum was omitted from the list of species.

In comparison with neighboring countries, where comprehensive information is available on the tick fauna (i.e., Croatia: Krčmar 2012; and Romania: Mihalca et al. 2012), the most notable difference is that in these two countries (situated south or southeast from Hungary, respectively) several thermophilic Rhipicephalus and Hyalomma species have long been indigenous. The above new data on the autochthonous occurrence of Rh. sanguineus and Hyalomma species in Hungary indicate the emergence (growing significance) of these species and suggest a shift towards a more thermophilic tick fauna.

Over the past decades, shifts were also noted in the distribution and abundance of certain tick species. Most remarkably, D. marginatus had been widespread in western Hungary (Janisch 1959), but according to our data it has receded from this region (Hornok and Farkas 2009). By contrast, D. reticulatus gradually emerged in western Hungary (first in two foci: Janisch 1959, then in a few further foci: Rehácek et al. 1979, Molnár 1982, Janisch 1986), and eventually it became widespread in both western and eastern parts of the country (Hornok and Farkas 2009). Similarly, based on the past rarity of I. frontalis (Janisch 1959) and Ha. inermis (Babos 1965), more recent data attest their emerging character in the country (Hornok and Farkas 2009; Hornok et al. 2016a).

Regarding the host preference data of ixodid tick species in Hungary, this is interrelated with the ecological traits (habitat preference and seasonal activity) of tick species, as shown above. First of all, the nidiculous nature of rodent-associated tick species and of larvae/nymphs of Dermacentor species, as well as the pholeophilous character of I. canisuga, I. kaiseri, I. hexagonus and some ornithophilic tick species (I. arboricola, I. lividus) precludes their collection from the vegetation (with dragging-flagging), therefore these have been exclusively collected from host animals (Hornok et al. 2013b, 2016a, 2017a).

On the other hand, for non-nidiculous tick species (all stages of Ixodes ricinus and Haemaphysalis species, adults of Dermacentor species), the local habitat type will define 
their occurrence on the vegetation, and this will entail consequences on their host associations, as reflected by the above data. In particular, sheep as grazing animals are more likely accessed by open country ticks (e.g. Dermacentor species: Hornok et al. 2007), as contrasted to goats which browse leaves, thus tend to be more exposed to forest-associated ticks (e.g. Ixodes species) (Hornok et al. 2012a). Similarly, it has been observed in Hungary that adult Dermacentor ticks predominate over I. ricinus on cattle grazing pastures, whereas this is equilibrated on wild ruminants occurring in both open country and forested habitats (Hornok and Horváth 2012).

The questing height may also be significantly different between sympatric tick species. For instance, I. ricinus larvae and nymphs appear to have reptiles, ground feeding birds and rodents as primary hosts (Földvári et al. 2009; Rigó et al. 2011; Hornok et al. 2016a). This is in contrast to Ha. concinna larvae and nymphs, which are usually associated with birds feeding above the ground level and roe deer (Hornok et al. 2012a, 2016a). Unlike in case of I. ricinus (with only larvae and nymphs infesting birds) in case of ornithophilic tick species adults were also collected from avian hosts, as exemplified by I. frontalis, I. festai, I. lividus and I. arboricola (Janisch 1959; Hornok et al. 2016a). In Hungary, rodents typically do not harbor I. ricinus adults (Rigó et al. 2011) which quest higher on the vegetation compared to larvae and nymphs, whereas hedgehogs and larger mammals can become infested with all three stages (Földvári et al. 2011; Hornok et al. 2012a) because these vertebrates get into contact with both the lower and somewhat higher vegetation. Apart from questing height, other host derived factors may also influence the host preference of tick developmental stages, because apparently both $D$. marginatus and $D$. reticulatus nymphs may feed on non-pet dogs (Hornok et al. 2013b), but typically only adults of D. reticulatus (but not of D. marginatus) on pet dogs (Földvári and Farkas 2005a).

Concerning humans as hosts of ixodid ticks, four species were involved in such cases in Hungary, namely I. ricinus, D. marginatus, D. reticulatus and Ha. inermis (Janisch and Szabó 1961; Janisch 1973; Földvári et al. 2013). Taking into account the range of preferred hosts (Fig. 5), apart from the most generalist species, I. ricinus, tick species only rarely connect wild animals and humans. On the contrary, all ixodid species which typically infest domestic animals, may also frequently infest humans. Interestingly, while it is estimated that in a worldwide context $27 \%$ of prostriate and $45 \%$ of metastriate ticks may use humans as hosts (Guglielmone and Robbins 2018), in Hungary the overall ratio of hitherto reported Palearctic tick species potentially infecting humans is $80.8 \%$ ( 21 of 26 ).

Last, but not least seasonal activity will also influence the occurrence of ticks and thus infestation of their hosts. The peak activity depends on weather variables and, as observed in Hungary, extreme temperature fluctuations (i.e., sharply rising temperatures during late winter) may trigger 1-2 month earlier questing peaks of those tick species, which have early to middle spring activity (Hornok 2009). In addition, data of this review reflect that the migratory habit of bird species (implying early or late spring arrival in Hungary) is interrelated with their tick infestation. In particular, short and middle-distance migratory birds (e.g. the Robin, Erithacus rubecula) arrive early spring, thus they most likely carry $I$. ricinus and I. frontalis larvae and nymphs; whereas long-distance migrant avian hosts (e.g. warblers, Locustella luscinioides and Acrocephalus species) return to Hungary late spring or early summer, and consequently will become infested most likely with Ha. concinna larvae and nymphs from the local tick fauna (Hornok et al. 2016a). 


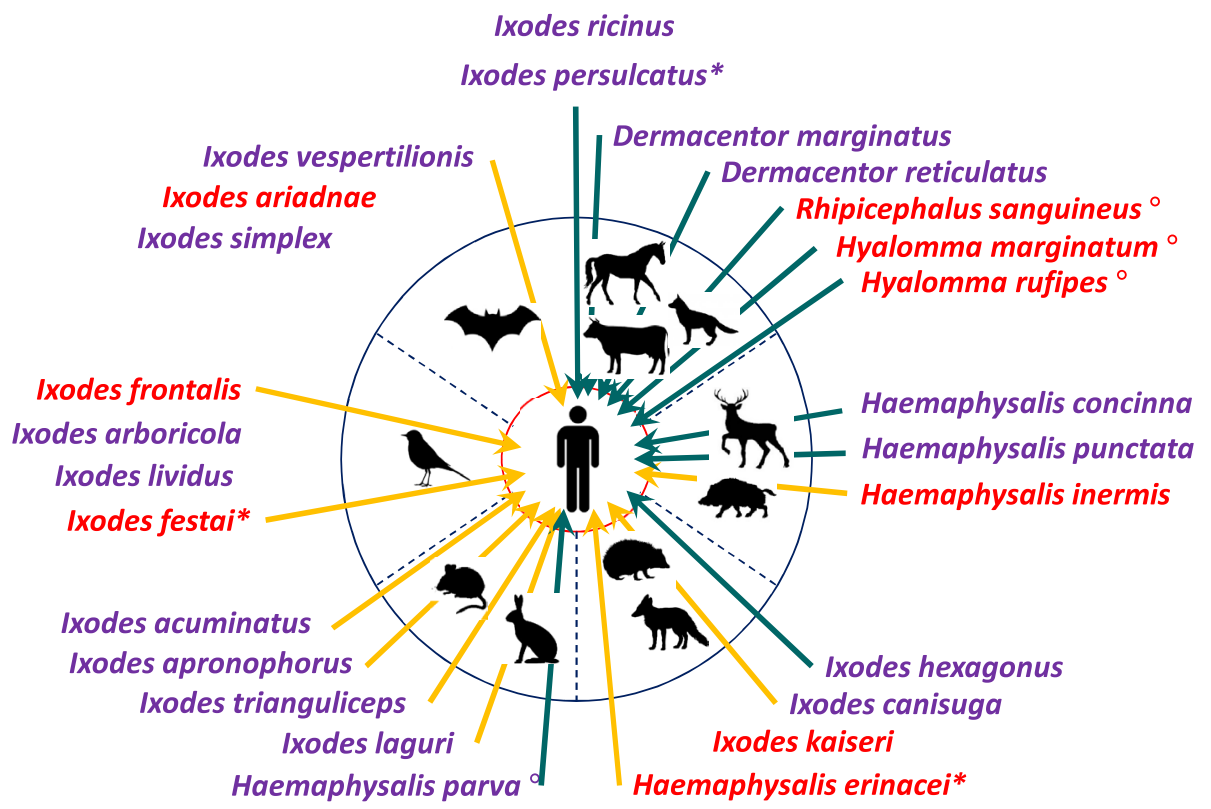

Fig. 5 Ixodid tick species identified so far in Hungary, which are Palearctic or known to molt in the country. All species are shown next to their preferred hosts (outer circle), connected to humans (in the center) with bluish green or yellow arrow according to their frequent or rare blood-sucking on humans, respectively, as reported (Guglielmone and Robbins 2018). Palearctic tick species, which have been imported but are non-indigenous in Hungary, are marked with asterisk (*). Autochthonous, but sporadic occurrence is indicated with a small circle $\left(^{\circ}\right)$ next to the species name. The names of emerging tick species (i.e., which were shown to increase in abundance or have only been identified in the past 15 years) are written in red color

Acknowledgements Open access funding provided by University of Veterinary Medicine (ÁTE). Sándor Hornok was supported by NKFI 130216. The authors thank for the contributions of Gábor Földvári, Levente Szilvássy and Sándor Kovalcsik to the sample collections.

Open Access This article is licensed under a Creative Commons Attribution 4.0 International License, which permits use, sharing, adaptation, distribution and reproduction in any medium or format, as long as you give appropriate credit to the original author(s) and the source, provide a link to the Creative Commons licence, and indicate if changes were made. The images or other third party material in this article are included in the article's Creative Commons licence, unless indicated otherwise in a credit line to the material. If material is not included in the article's Creative Commons licence and your intended use is not permitted by statutory regulation or exceeds the permitted use, you will need to obtain permission directly from the copyright holder. To view a copy of this licence, visit http://creativecommons.org/licenses/by/4.0/.

\section{References}

Babos S (1964) Die Zeckenfauna Mitteleuropas. Akadémiai Kiadó, Budapest, p 410 (in German). Babos S (1965) Kullancsok - Ixodidea [Ticks - Ixodidea]. Fauna Hungariae 18:1-38 (in Hungarian) Bartholy J, Pongrácz R, Gelybó G (2007) Regional climate change expected in Hungary for 2071-2100. Appl Ecol Environ Res 5:1-17

Camicas JL, Hervy JP, Adam F, Morel PC (1998) Les tiques du monde. Nomenclature, stades décrits, hôtes, répartition (Acarida, Ixodida). Orstom, Paris, p 233 (In French). 
Contini C, Palmas C, Seu V, Stancampiano L, Usai F (2011) Redescription of the male of Ixodes festai Rondelli, 1926 (Ixodida: Ixodidae) on specimens from Sardinia (Italy). Parasite 18:235-240

Estrada-Peña A, Mihalca AD, Petney TN (2017) Ticks of Europe and North Africa: a guide to species identification. Springer International Publishing, Cham, p 404

Farkas R, Solymosi N, Takács N, Hornyák Á, Hornok S, Nachum-Biala Y, Baneth G (2014) First molecular evidence of Hepatozoon canis infection in red foxes and golden jackals from Hungary. Parasit Vectors 7:303

Földvári G, Farkas R (2005a) Ixodid tick species attaching to dogs in Hungary. Vet Parasitol 129:125-131

Földvári G, Farkas R (2005b) Review of literature relating to Dermacentor reticulatus (Acari: Ixodidae) and newer data on the occurrence in Hungary. Magy Állatorvosok 127:289-298 (in Hungarian with English summary)

Földvári G, Márialigeti M, Solymosi N, Lukács Z, Majoros G, Kósa JP, Farkas R (2007) Hard ticks infesting dogs in Hungary and their infection with Babesia and Borrelia species. Parasitol Res 101(Suppl 1):25-34

Földvári G, Rigó K, Majláthová V, Majláth I, Farkas R, Pet'ko B (2009) Detection of Borrelia burgdorferi sensu lato in lizards and their ticks from Hungary. Vector Borne Zoonotic Dis 9:331-336

Földvári G, Rigó K, Jablonszky M, Biró N, Majoros G, Molnár V, Tóth M (2011) Ticks and the city: ectoparasites of the Northern white-breasted hedgehog (Erinaceus roumanicus) in an urban park. Ticks Tick Borne Dis 2:231-234

Földvári G, Rigó K, Lakos A (2013) Transmission of Rickettsia slovaca and Rickettsia raoultii by male Dermacentor marginatus and Dermacentor reticulatus ticks to humans. Diagn Microbiol Infect Dis 76:387-389

Guglielmone AA, Robbins RG (2018) Hard ticks (Acari: Ixodida: Ixodidae) parasitizing humans. Springer, Dordrecht, p 314

Guglielmone AA, Robbins RG, Apanaskevich DA, Petney TN, Estrada-Peña A, Horak IG (2014) The hard ticks of the world. Springer, Dordrecht, p 738

Gyuranecz M, Rigó K, Dán A, Földvári G, Makrai L, Dénes B, Fodor L, Majoros G, Tirják L, Erdélyi K (2011) Investigation of the ecology of Francisella tularensis during an inter-epizootic period. Vector Borne Zoonotic Dis 11:1031-1035

Hoogstraal H (1956) African Ixodoidea-I. Ticks of the Sudan. Washington, DC: US Department of the Navy, Bureau of Medicine and Surgery, p 480-489.

Hornok S (2009) Allochronic seasonal peak activities of Dermacentor and Haemaphysalis spp. under continental climate in Hungary. Vet Parasitol 163:366-369

Hornok S, Farkas R (2005) First autochthonous infestation of dogs with Rhipicephalus sanguineus (Acari: Ixodidae) in Hungary: case report and review of current knowledge on this tick species. Magy Állatorvosok 127:623-629 (in Hungarian with English summary)

Hornok S, Farkas R (2009) Influence of biotope on the distribution and peak activity of questing ixodid ticks in Hungary. Med Vet Entomol 23:41-46

Hornok S, Horváth G (2012) First report of adult Hyalomma marginatum rufipes (vector of Crimean-Congo haemorrhagic fever virus) on cattle under a continental climate in Hungary. Parasit Vectors 5:170

Hornok S, Elek V, de la Fuente J, Naranjo V, Farkas R, Majoros G, Földvári G (2007) First serological and molecular evidence on the endemicity of Anaplasma ovis and A. marginale in Hungary. Vet Microbiol $122: 316-322$

Hornok S, Horváth G, Jongejan F, Farkas R (2012a) Ixodid ticks on ruminants, with on-host initiated moulting (apolysis) of Ixodes, Haemaphysalis and Dermacentor larvae. Vet Parasitol 187:350-353

Hornok S, Micsutka A, Fernández de Mera IG, Meli ML, Gönczi E, Tánczos B, Mangold AJ, Farkas R, Lutz H, Hofmann-Lehmann R, de la Fuente J (2012b) Fatal bovine anaplasmosis in a herd with new genotypes of Anaplasma marginale, Anaplasma ovis and concurrent haemoplasmosis. Res Vet Sci 92:30-35

Hornok S, Csörgő T, de la Fuente J, Gyuranecz M, Privigyei C, Meli ML, Kreizinger Z, Gönczi E, Fernández de Mera IG, Hofmann-Lehmann R (2013a) Synanthropic birds associated with high prevalence of tick-borne rickettsiae and with the first detection of Rickettsia aeschlimannii in Hungary. Vector Borne Zoonotic Dis 13:77-83

Hornok S, de la Fuente J, Horváth G, Fernández de Mera IG, Wijnveld M, Tánczos B, Farkas R, Jongejan F (2013b) Molecular evidence of Ehrlichia canis and Rickettsia massiliae in ixodid ticks of carnivores from South Hungary. Acta Vet Hung 61:42-50

Hornok S, Kontschán J, Kováts D, Kovács R, Angyal D, Görföl T, Polacsek Z, Kalmár Z, Mihalca AD (2014a) Bat ticks revisited: Ixodes ariadnae sp. nov. and allopatric genotypes of I. vespertilionis in caves of Hungary. Parasit Vectors 7:202 
Hornok S, Kováts D, Csörgő T, Meli ML, Gönczi E, Hadnagy Z, Takács N, Farkas R, Hofmann-Lehmann R (2014b) Birds as potential reservoirs of tick-borne pathogens: first evidence of bacteraemia with Rickettsia helvetica. Parasit Vectors 7:128

Hornok S, Mester A, Takács N, Fernández de Mera IG, de la Fuente J, Farkas R (2014c) Re-emergence of bovine piroplasmosis in Hungary: has the etiological role of Babesia divergens been taken over by $B$. major and Theileria buffeli? Parasit Vectors 7:434

Hornok S, Meli ML, Gönczi E, Halász E, Takács N, Farkas R, Hofmann-Lehmann R (2014d) Occurrence of ticks and prevalence of Anaplasma phagocytophilum and Borrelia burgdorferi s.l. in three types of urban biotopes: forests, parks and cemeteries. Ticks Tick Borne Dis 5:785-789

Hornok S, Flaisz B, Takács N, Kontschán J, Csörgő T, Csipak Á, Jaksa BR, Kováts D (2016a) Bird ticks in Hungary reflect western, southern, eastern flyway connections and two genetic lineages of Ixodes frontalis and Haemaphysalis concinna. Parasit Vectors 9:101

Hornok S, Szőke K, Kováts D, Estók P, Görföl T, Boldogh SA, Takács N, Kontschán J, Földvári G, Barti L, Corduneanu A, Sándor AD (2016b) DNA of piroplasms of ruminants and dogs in Ixodid bat ticks. PLoS ONE 11:e0167735

Hornok S, Sándor AD, Beck R, Farkas R, Beati L, Kontschán J, Takács N, Földvári G, Silaghi C, MeyerKayser E, Hodžić A, Tomanović S, Abdullah S, Wall R, Estrada-Peña A, Duscher GG, Plantard O (2017a) Contributions to the phylogeny of Ixodes (Pholeoixodes) canisuga, I. (Ph.) kaiseri, I. (Ph.) hexagonus and a simple pictorial key for the identification of their females. Parasit Vectors 10:545

Hornok S, Sándor AD, Tomanović S, Beck R, D’Amico G, Kontschán J, Takács N, Görföl T, Bendjeddou ML, Földvári G, Farkas R (2017b) East and west separation of Rhipicephalus sanguineus mitochondrial lineages in the Mediterranean Basin. Parasit Vectors 10:39

Hornok S, Mulvihill M, Szőke K, Gönczi E, Sulyok KM, Gyuranecz M, Hofmann-Lehmann R (2017c) Impact of a freeway on the dispersal of ticks and Ixodes ricinus-borne pathogens: forested resting areas may become Lyme disease hotspots. Acta Vet Hung 65:242-252

Hornok S, Horváth G, Takács N, Kontschán J, Szőke K, Farkas R (2018) Molecular identification of badgerassociated Babesia sp. DNA in dogs: updated phylogeny of piroplasms infecting Caniformia. Parasit Vectors 11:235

Janisch M (1959) A hazai kullancsfauna feltérképezése [Geographical distribution of tick species in Hungary]. Állattani Közl 47:103-110 (in Hungarian)

Janisch M (1960) Kullancsgazda madarak különféle betegségek közvetítői [Birds as tick hosts spreading various diseases]. Aquila 67-68:191-194 (in Hungarian with German summary)

Janisch M (1973) Adatok a Bakony hegység kullancsfaunájához [Data to the tick fauna of the Bakony Mountains]. A Veszprém Megyei Múzeumok Közleményei 12:513-516 (in Hungarian with English and German summary)

Janisch M (1986) Dermacentor pictus tick species as the vector of Babesia canis in Hungary. Magy Állatorvosok 41:310-312 (In Hungarian with English, German and Russian summary)

Janisch M, Szabó I (1961) Adatok a Börzsöny hegység kullancsfaunájához [Data to the tick fauna of the Börzsöny Mountains]. Vertebr Hungarica 3:147-156

Kotlán S (1921) A hazai kullancsok rendszere [Systematics of hard ticks of Hungary]. Állattani Közl 20:4350 (in Hungarian)

Krčmar S (2012) Hard ticks (Acari, Ixodidae) of Croatia. Zookeys 234:19-57

Mihalca AD (2015) Ticks imported to Europe with exotic reptiles. Vet Parasitol 213:67-71

Mihalca AD, Dumitrache MO, Magdaş C, Gherman CM, Domşa C, Mircean V, Ghira IV, Pocora V, Ionescu DT, Sikó Barabási S, Cozma V, Sándor AD (2012) Synopsis of the hard ticks (Acari: Ixodidae) of Romania with update on host associations and geographical distribution. Exp Appl Acarol 58:183-206

Molnár E (1982) Occurrence of tick-borne encephalitis and other arboviruses in Hungary. Geogr Med 12:78-120

Petney TN, Pfäffle M, Skuballa J (2012) An annotated checklist of the ticks (Acari: Ixodidae) of Germany. Syst Appl Acarol 17:115-170

Pintér R, Madai M, Vadkerti E, Németh V, Oldal M, Kemenesi G, Dallos B, Gyuranecz M, Kiss G, Bányai $\mathrm{K}$, Jakab F (2013) Identification of tick-borne encephalitis virus in ticks collected in southeastern Hungary. Ticks Tick Borne Dis 4:427-431

Rehácek J, Nosek J, Urvölgyi J, Sztankay M (1979) Rickettsiae of the spotted fever group in Hungary. Folia Parasitol 26:367-371

Rigó K, Gyuranecz M, Tóth AG, Földvári G (2011) Detection of Borrelia burgdorferi sensu lato and Anaplasma phagocytophilum in small mammals and ectoparasites in Hungary. Vector Borne Zoonotic Dis 11:1499-1501

Sréter T, Széll Z, Varga I (2003) Ectoparasite infestations of red foxes (Vulpes vulpes) in Hungary. Vet Parasitol 15:349-354 
Széll Z, Sréter-Lancz Z, Márialigeti K, Sréter T (2006) Temporal distribution of Ixodes ricinus, Dermacentor reticulatus and Haemaphysalis concinna in Hungary. Vet Parasitol 141:377-379

Szép T, Møller AP (1999) Cost of parasitism and host immune defence in the sand martin Riparia riparia: a role for parent-offspring conflict? Oecologia 119:9-15

Publisher's Note Springer Nature remains neutral with regard to jurisdictional claims in published maps and institutional affiliations. 